\title{
ARTIKEL III VAN DIE KERKWET VAN DIE NEDERDUITSCH HERVORMDE KERK VAN AFRIKA
}

„Die Kerk, bewus van die gevare wat vermenging van Blank en nieBlank vir altwee groepe inhou, wil geen gelykstelling in sy midde toelaat nie, maar beoog die stigting van eie volkskerke onder die verskillende volksgroepe, in die oortuiging dat aldus die bevel van die Here: „Maak dissipels van al die nasies, Matt. 28:19, die beste tot sy reg sal kom en dat die eenheid in Christus deur so 'n werkverdeling nie geskaad sal word nie. Tot die Nederduitsche Hervormde Kerk van Afrika behoort daarom slegs Blanke persone".

Inleiding

In artikel III van ons kerkwet, word enkele baie belangrike stellings neergelê, waarvan die sin en die inhoud so oud is as die Nederduitsch Hervormde Kerk self. Al hierdie stellings het te doen met die christelike geloof waardeur die vroegste voorgeslagte van die Hollands-Afrikaans- 
sprekende boerevolk gedra is en as christenvolk staande gehou is al die jare deur. Afgesien van die moderne probleme van apartheid of vennootskap, segregasie of integrasie, nasionalisme of internasionalisme, idealisme of materialisme, ens. bevat hierdie artikel dus elemente, wat gesien moet word as van die allerkosbaarste erfenisse en kleinode wat aan ons geslag oorgedra is van die geloofsinhoud van christelike helde en heldinne soos die Hollandse Watergeuse en Franse Hugenote, wie se geloof en lewensopvatting gebore was uit die calvinistiese Protestantisme en gelouter is deur jare-lange stryd vir hulle geestelik-godsdienstige bestaan, voordat hulle verhuis het na Suid-Afrika om hier 'n nuwe vaderland te soek, waar hulle vry kon uitleef, waar hulle in Europe vaak tevergeefs voor geleef en gesterf het. Dat hulle nie hierheen gekom het, omdat hulle agter goud en diamante aangetrek het nie maar om hulle geestelik-godsdienstige vryheid en hulle christelik-nasionale lewensopvatting te kan uitleef, het meegebring dat hulle geloofsbeskouing en lewensopvatting, soos wat dit voortgeleef het by hulle nageslagte in latere tye, in botsing moes kom met die lewensopvatting van mense, wat Suid-Afrika hulle tuiste gemaak het omrede van die stoflike bestaan en ons land alleen terwille van sy goud en edelgesteentes hooggewaardeer het. Hierdie botsing wat al meer as 150 jaar aan die gang is en in ons tyd nog altyd skerper en bitterder word, het meegebring dat daar vandag groot vraagtekens gestel word agter hierdie deur ons hooggewaardeerde christelike erfenisse van die calvinistiese geloofsbeskouing, soos onder ander ook tot uiting kom in artikel III van ons kerkwet.

Daarom kan die vraag: of artikel II wel nog uiting gee aan ons opvatting van onder meer die verhouding wat daar moet bestaan tussen die verskillende rasse metname die gekleurde rasse binne die grense van die christelike kerk, ook vertolk word as die vraag: of die lidmate van ons kerk en die lede van ons volk nog wel bereid is om hulle te laat bind deur die christelike beginsels van die verre voorgeslagte? Het ons nou al so ontwikkel en so verander, dat hierdie artikel verander moet word en vervang moet word deur iets anders, of ten minste anders geformuleer behoort te word? Laat ons die verskillende stellings kortliks stel.

\section{Die Stellings in Artikel III.}

(1) Daar word gepraat van ,geen gelykstelling tussen Blank en nieBlank in sy midde". Hier word geen beswaar gemaak nie, soos wat so vaak beweer word, teen gelykstelling sondermeer, maar alleen teen gelykstelling in dieselfde sosiale struktuur. Hier word geen beswaar gemaak nie teen gelyke kerklike voorregte. Wat aan die Blanke gegun word op kerklike godsdienstige gebied moet ook aan die nie-Blanke gegun word. En waar daar op kultureel maatskaplike terrein verskille bestaan, verskille kragtens verskil van ras, volk, kultuur ens. daar is dit nie die taak van die kerk nie om hierdie verskille op te hef, want God is die Skepper van rasse, volke en tale. Dus geen opsetlike vermenging nie. 
(2) In die tweede plek word die stelling neergelê: dat 'n sodanige vermenging gevaarlik is. Die gevare kan hier van allerlei aard wees. Gevaarlik was en is dit veral vir die eerbiediging van die verskeidenheid in die skeppingswerk van God. Maar kerklike gelykstelling in dieselfde kring, as dit opreg bedoel is en sonder voorbehoud toegepas word, kan en moet en behoort te lei tot die verwydering van alle maatskaplike verskille en moet dan ook lei tot bloedvermenging, wat algemeen aanvaar word skadelik te wees vir kultuur en godsdiens beide.

(3) 'n Derde stelling is: dat dit die christelike plig van die Nederduitsch Hervormde Kerk is om die Evangelie te verkondig aan alle mense, ook die nie-Blankes en hulle te versamel binne die grense van die kerk van Christus, maar dat hulle as christene gegroepeer moet word binne hulle eie christelike kerkgenootskappe. Daar sal dus nie alleen verskillende kerkgenootskappe onder die Blankes bestaan nie, maar ook onder die nieBlankes. Elke volksgroep sal ten minste een eie kerkgenootskap hê.

(4) 'n Vierde stelling word neergelê naamlik dat as die christelike kerk langs hierdie natuurlike weg onder al die verskillende volksgroepe en kultuurgroepe georden word en hulle so gevrywaar word van allerlei vorms van kulturele stryd en selfs vreedsaam naasmekaar kan bestaan, die bevel van die Here: „maak dissipels van al die nasies”, die beste tot sy reg sal kom en dat die eenheid in Christus deur so 'n werkverdeling nie geskaad sal word nie.

\section{Die Besware teen hierdie Stellings.}

Teenoor hierdie stellings word in die moderne wêreld, die naoorlogse wêreld, en veral van die kant van modernistiese kringe, selfs in ons eie land, allerlei besware na vore gebring. Die besware is van verskillende aard maar het gewoonlik 'n gemeenskaplike bron:-

(1) Die kerk, geen kerk, het die reg om hierdie natuurlike verskille te handhaaf of te eerbiedig nie, as hy die kerk van Christus wil wees, want alle gelowiges is skepsels van God in Christus. Die christelike is daar om die natuurlike te vervang te herstel of te verbeter, want deur die geloof in Christus is al die mure van afskeidsels afgebreek en weggebreek. En waar die verskeidenheid in die natuur hier verwerp word as wenslik, kom die handhaaf van verskille neer op die een of ander vorm van ,diskriminasie" van die een ras of volk teenoor 'n ander, iets wat tussen Christus-gelowiges nie mag bestaan nie.

(2) Die Skrif gee geen reg om sulke verskille te handhaaf nie. Inteendeel dit wys dat die teenoorgestelde bedoel word in die kerk van Christus. Dit sou anders die eenheid van Christus, wat ons met die Apostolikum bely in gevaar bring en daarvan 'n karikatuur maak.

(3) Die eenheid van die christelike kerk moet as geloofseenheid ook werklik bestaan, dit wil sê dit moet sigbaar wees, anders is dit geen werklikheid nie. 
Dit is min-of-meer 'n samevatting van al die besware, wat van verskillende kante ingebring word-meesal onder Anglikaanse invloedteen die rasse-beleid waarvan artikel III van ons kerkwet ook uiting wil gee.

\section{Die Weerlegging van hierdie Besware.}

Al die genoemde besware staan in verband met die gees van die tyd waarin ons leef. Dis helaas 'n gees wat nie net die sin en betekenis van die christelike geloof nie beklemtoon nie, maar wat ook die geloof in Christus en die bestaan van sy kerk as 'n tydverskynsel opvat. Die gees van die tyd is 'n gees van gelykmaking van alles en die uitwissing van alle verskille op alle terreine. Die verskeidenheid word aangesien vir verskeurdheid van die menslike geslag en kan onmoontlik in ooreenstemming met die wil van God wees. Hierdie gees van gelykmaking tussen rasse, volke, kulture en groepe is die gees van die wêreld van vandag. Sat van oorlog en sat van twis en stryd en sidderend vir die botsings wat kom, verlang die mens van vandag na die uitwissing van alle verskeidenheid. As dit maar eers gebeur het, sal die ewigdurende vrede hier op aarde aanbreek. Hierdie verlange na 'n kleurlose en siellose eenheid is die siekte van die wêreld van vandag en-dit is 'n siekte tot die dood toe. Waar die verskeidenheid op alle terreine van die lewe gesien word as die groot oorsaak van onenigheid en twis, word dit ook opgevat as iets onnatuurliks. Dat die verskeidenheid die voorwaarde is van alle lewe en dat dit die lewe so ryk en so diep maak, waar daar 'n vreedsame bestaan naasmekaar is, kan hier nie ingesien word nie. Dat die sonde die oorsaak is van twis en stryd, weet die wêreld van vandag nie meer nie, omdat hy van sonde niks wil weet nie en daarom word die oorsaak van die onvrede gesoek in die natuurlike verskeidenheid.

Ons beleef ' $n$ tyd wat gesien kan word as 'n herhaling en herlewing van die Hellenisme, 'n kultureel religieuse verskynsel, wat die wêreldgees vir ongeveer ses honderd jaar beheers het van plus minus 300 V.C. tot plus-minus 300 N.C. Dit het begin met die groot verowerings van Alexander die Grote, wat vir hom die ideaal gestel het van een groot koninkryk van baie rasse, volke en tale, Grieke en barbare. Dit het as einddoel gehad die opheffing van alle verskille en verskeidenheid in kultuur sowel as godsdiens. Dit het meegebring 'n vermenging van al wat oosters en wat westers was, maar met die ooste altyd in die sterkste posisie, net soos met die gelykmakingsproses van die wêreld van vandag ook die geval is. Dit wil sê nie dat hierdie gelykmakingsproses van plus-minus 2000 jaar gelede heeltemal vrugteloos was nie. Dat die wegneem van groot verskille soos die tussen man en vrou, tussen slaaf en slaafeienaar, heilsame vrugte afgewerp het, is nie te betwyfel nie. Maar die kleurlose eenheid sonder verskeidenheid is in stryd met alles wat natuurlik is en- die lewe is natuurlik. Daarom was hierdie strewe na 'n kleurlose eenheid 'n mislukking. So 'n eenheid bestaan net dáár waar die dood heerskappy voer en só was die tyd van die Hellenisme feitlik 'n heerskappy van die dood. Vandaar dat die wêreld toe ook voorberei was vir die koms van Christus, wat geen 
nuwe kultuur gebring het nie, maar die waaragtige lewe as antwoord op die soek na geluk en vrede van die Hellenisme. Dis die Christendom wat die Hellenisme oorwin het en só die wêreld verlos het van 'n gewisse dood.

So moet ons ook die gees van ons tyd sien. Die materialisme het in die twee afgelope wêreldoorloë die stryd gewin teen enige vorm van idealisme en namate hy sy magte al meer en meer ontplooi in die wêreld, na die mate verloor die christelike kerk en die christelike geloof die stryd in die wêreld van vandag. Dat die christelike kerk in ons tyd al meer en meer begin deelneem aan en meedoen met hierdie gelykmakingsproses voorspel niks goed vir die kerk nie. Dit getuig nie van sy geloofskrag nie maar van die teendeel naamlik van 'n sterwende geloof. Daarom ook die verskynsel dat daardie dele van die christelike kerk, wat die voorvegters is van 'n deelneem aan die wêreldse gelykmakingsproses 'n vorm van christelike geloof verdedig wat dit nie werd is nie om voor te leef, nog minder om voor te sterf. Hieronder vind mens groepe van christene, wat die christelike klok wel gehoor lui het, maar nie weet nie waar die klepeltjie hang.

Maar waar hierdie kerklike groepe die materialistiese wêreld van vandag as sy wapenbroer het, voorspel dit 'n kwaaie dag en donker toekoms vir die christelike geloof. Dis die bedreigings teen die kerk van binne uit en wat die kerk veel meer skade kan doen as die aanvalle van buite. Die begeerte om trots die natuurlike verskeidenheid in die kerk 'n fisiessigbare eenheid tot stand te bring, is nie uit die geloof gebore nie maar uit die ongeloof. Dit is die ongeloof wat geen onderskeid meer kan maak nie tussen die psigies-natuurlike aan die een kant en die geestelik-pneumatiese aan die ander kant, net soos die modernistiese rigtings in die teologie van die $19 \mathrm{de}$ eeu. Die pneumaties-geestelike word sondermeer vereenselwig met die menslik-psigiese en die tydelik-verganklike met die GoddelikEwige. Die geloof aan die verskil tussen die Ewige en die tydelike, die Goddelike en die menslike het hier onbetwisbaar verlore gegaan.

Van die christelike kerke in ons land, wat die stryd stry vir 'n wêreldgesinde gelykmakingsproses staan die Anglikaanse kerk op die voorpunt. Vir sover dit 'n teologie of beter nog 'n filosofie het, is dit flagrant in stryd met die Calvinisme van die Afrikaanse kerke. Waar dit altyd angstig soek na 'n redelike basis vir sy christelike geloof soos vir enige ander godsdiens, verwerp dit die Skrif as die enigste Woord van God, die Skrif wat die enigste grondslag van die Calvinisme is. Christelike teologie is die teologie met die Skrif as sy uitgangspunt, sy grond en norm. En die teologie wat dit nie doen nie, mag 'n filosofiese sisteem wees, maar geen christelike teologie nie. Dit is ook hierdie christene wat die vrymoedigheid het om die Afrikaanse kerk aan te val. 'n Mens moet stom en dom wees as hy met klippe begin te gooi terwyl jy in 'n huis van glas woon.

En helaas is daar ook lede van die Afrikaanse kerke, wat onder die invloed van hierdie sogenaamde christelike teologie ook die spoor van die 
christelike teologie byster geraak het, ook 'n gelykmakingsproses verdedig binne die grense van die kerk, ook 'n sigbare eenheid onder alle gelowiges van alle rasse, volke en kleure tot stand wil bring en ook die geloofseenheid nieteenstaande verskillende rasse, volke, kulture en kerkgenootskappe, verwerp. In hulle eie kerk vind hulle geen rus vir die holte van hulle voet nie en skop teen alles wat hulle in die weg staan en teen alle bepalings, soos wat vervat is in artikel III van die kerkwet.

Maar laat ons nou in die lig van alles wat hierbo gesê is omtrent die stellings wat in artikel III neergelê is 'n antwoord soek op die vraag: of die artikel nog uiting gee aan wat leef in die siel van die lidmate van die kerk en of dit nog konform die Woord van God is?

(1) In die eerste plek dan die geskeidenheid van Blank en nie-Blank binne die grense van die kerk en van elke gemeente. Die teenstanders van hierdie artikel verwerp die stelling, omdat hulle meen dat hier tot uiting kom, 'n afskuwelike vorm van diskriminasie, wat voor God en gewete nie verantwoord kan word nie. Dat enige vorm van diskriminasie dit wil sê die een mens of die een volk of groepe van volke, van minder waarde en betekenis ag as my eie persoon of volk of ras, enige christenmens onwaardig is en voor God en gewete nie verantwoord kan word nie, is beslis waar. Maar juis daarom staan die Afrikaanse kerk, ons volk en enige christenmens vir aparte ontwikkeling en aparte bestaan vir elke ras, groep of volk.

Hier speel diskriminasie geen rol nie maar word hier juis uitgeskakel. Hierdie geskeidenheid bring inderdaad mee 'n gesonde verhouding van gelykheid tussen sodanige rasse, volke of groepe, maar dan apart en territoriaal geskeie. Dit is gelykheid maar nie ,gelykheid in sy midde" nie. Dit is hierdie rassebeleid wat gebore is uit die christelik-nasionale lewensopvatting van die Afrikaner, soos wat ons dit by elke christenmens behoort te vind. Dis die beleid wat gebou is op 'n christelik-nasionale klasseverdeling in teenstelling met die internasionalisties-materialistiese klasseverdeling van die kapitalisme en kommunisme. Dit wil sê die mensemassa word hiervolgens verdeel in rasse, volke en groepe na die aard van hulle ras en bloed of na die aard van hulle godsdiens en nie na die manier waarop hulle hul brood verdien nie. Dit is netsomin 'n vorm van diskriminasie as wat die handhawing van die geskeidenheid van aparte huisgesinne diskriminasie sou wees. 'n Volk is 'n groot huisgesin, 'n huisgesin van husigesinne. Waar die huisgesin as 'n aparte en selfstandige entiteit instand gehou word, daar volg van nature die ideaal om die volk ook só instand te hou. En hierdie ideaal geld volgens die christelik-nasionale lewensopvatting nie net vir die eie ras of volk of groep nie, maar vir elke ander ras of volk of groep. Want hier is sprake van 'n nasionalisme, wat christelik gefondeer is en christelik geregverdig kan word. God is die Skepper van rasse en volke en groepe. Dit leer ons uit Gen. 11 ook al. Die christengelowige verlang vir homself alleen wat hy aan elke ander skepsel van God ook gun. Hierdie geskeidenheid 
van naasmekaar bestaande rasse, volke of groepe, wat ons gemakshalwe „positiewe apartheid" noem, is in laaste instansie gefondeer op die liefde tot die naaste, die tweede tafel van die dekaloog, wat weer gegrond is in die liefde tot God, die almagtige Skepper van alles wat bestaan. Daarom is die positiewe apartheid of christelike apartheid, nie alleen die enigste christelike grond vir die bepaling van die verhouding tussen rasse, volke en groepe nie, maar ook die enigste natuurlike grond, die enigste regverdige grond en ook die enigste vreedsame grondslag. Dit is wat die Afrikaner van die vroegste begin in Suid-Afrika beoog het. Maar deurdat die ander rasse en volke nog onbekwaam was om hierdie verantwoordelikheid en nasieskap te aanvaar, het die Blanke christen homself gaan sien as die voog van die nie-Blanke, 'n voogdyskap wat natuurlik nie altyd kon duur nie en ook nooit so bedoel was nie.

Die teenstelling hiervan is wat integrasie genoem word. Dis die vermenging van alles wat met die spraakverwarting by die toring van Babel reeds deur God self verwerp is en wat deur die materialistiese klasseverdeling van die kapitalisme en die kommunisme, hierdie tweeling broers, in ere herstel wil word. Hierdie materialistiese klasseverdeling staan ook 'n vorm van apartheid voor, maar dis 'n negatiewe vorm van apartheid of geskeidenheid, wat op materialistiese geskeidenheid gegrond is en wat altyd gepaard gaan met die afskuwelikste vorms van diskriminasie. Dis hierdie vorm van apartheid wat on-christelik en heidens is, die stryd waarteen as gebod van God gesien moet word. Daar is in ons land helaas ook bestryders van die christelik-nasionale apartheid, omdat hulle dit kortsigtelik vereenselwig met die negatiewe apartheid van die materialisme. Is dit dan ' $n$ wonder dat in hierdie selfde kringe, waar die verwydering van alle gekeidenheid binne die christelike kerk, verdedig word, vanself daartoe oorgaan om diskriminerend onderskeid te maak tussen die vergoeding en voorregte van Naturelle leraars teenoor Blanke leraars, van Naturelle arbeiders teenoor Blanke arbeiders, al word dieselfde werk verrig. Is dit 'n wonder dat voorgestel word dat die nie-Blankes liewer toegang gegee moet word tot die kerkgeboue van die Blankes as om vir hulle 'n eie kerkgebou op te rig, met die diskriminerende bepaling daarby dat hulle maar net op die paar agterste rye banke mag sit. Die hele materialistiese klasseverdeling is van christelike standpunt uit gesien op diskriminasie gebou en daarom verwerplik en verdoemlik. Dit getuig nie van die bloei van die christelike geloof nie maar van sy verval. En wee ons wanneer hierdie pseudo-christendom die geestelike leiding aan die ongelukkige wêreld van vandag moet gee. Dis daardie gedeelte van die christendom wat al wat christelik is verloën het en tot die heidendom teruggesink het. Sal die blindes dan in die wêreld van vandag leiding moet gee?

(2) Die tweede stelling is dat so 'n vermenging van rasse en kleure, waar die christelik-nasionale apartheid verwerp word, lewensgevaarlik is vir die bestaan en die voortbestaan van Blank sowel as nie-Blank. 
Dis gevaarlik omdat die familiariteit en sosiale gelykheid in dieselfde kring wat hier anders gekweek word, aanleiding moet gee tot alle ander vorms van familiariteit, ook ondertrouery. Dis inderdaad ook wat beoog word deur alle voorstanders van integrasie. Gelukkig maar dat daar toenemende tekens is dat alle reggeaarde Naturelle en Kleurlinge hierdie doelstelling met die grootste veragting verwerp.

Die reggeaarde christen erken die geskeidenheid en verskille tussen rasse, volke en groepe as Gods werk en daarom natuurlik en ook wenslik. Die erkenning van hierdie feit is vir hom Gods gebod. Hy leer dit in die Skrif en daarom wil hy die geëerbiedig sien. Die wat die verskeidenheid verwerp en gevolglik ook 'n natuurlike geskeidenheid en 'n vermenging verdedig, is besig met die vernieting van Gods werk en die bou van 'n nuwe toring van Babel. Ook hier is vir die christengelowige die Woord van God in die Skrif sy gids en leidsman: „Jy moet jou naaste liefhê, net soos jouself".

(3) Die derde stelling raak die sendingsaktiwiteit van die kerk. Die deur God gegewe en gewilde verskeidenheid moet ook hier geëerbiedig word en alleen só kan die verkondiging van die Evangelie behartig word tot seën van die minder bevoorregte rasse, volke en groepe. Die sending onder die heidene moet uitloop op die ontstaan van die volkskerke. Die sendingsbeleid van die Nederduitsch Hervormde Kerk beoog die ideaal van volkskerstening. Dit wil rekening hou met die nasionale faktore dit wil sê die karakter en eie aard van elke etniese groep. Dit wil eerbiedig sien die eie aard en karakter en kultuur van elke groep, aan wie die Evangelie gebring moet word. Die godsdienstige lewe moet deur die prediking van die Evangelie by elke groep 'n eie gestalte aanneem. Die beskouing word hier indirek verwerp dat sending die oordrag van die westerse kultuur aan die swartman moet wees om so van hom inderdaad 'n swart Europeaan te maak. Dis alweer net die Europeër of Blanke, wat gedra word deur grenselose „Herrenvolk”-gedagte en geen waardering het nie vir die kultuur van die swartman, wat hierdie ideaal vir hom kan stel. Maar die twryfelagtige oorsprong van sy christendom maak al weer dat hy geen verskil kan raaksien nie tussen Evangelie en kultuur en daarom is sy Evangelie-prediking niks anders nie as kultuur-oordrag. Dat hierdie soort van Evangelie-prediking aan en die kerstening van die nie-Blanke deur enige nasionaal ontwakende volk verwerp en verag word, daarvan kan talle voorbeelde uit die sendingsaksie, in Asië sowel as Afrika getuig. Die Evangelie-prediking wat vrugte wil dra moet aansluit by die nasionale lewe van elke etniese groep en langs die weg van reformasie uit elke kultuur wegruim wat met die Woord van God strydig is.

(4) In die vierde en laaste stelling word ook verder neergelê dat alleen só langs die weg van eerbiediging van die verskeidenheid van tasse volke en groepe en die wederkerige waardering van die kultuureie van elke groep, die kerk werklik gebou en uitgebrei kan word en die geloofseenheid van die kerk as geheel gehandhaaf word. 
Waar daar van onbybelse en onchristelike vooronderstellings uitgegaan word, moet natuurlik ook onbybelse en onchristelike doelstellings vir die sendingsaktiwiteit volg. En as die sendingsaktiwiteit beoog 'n christendom wat volg op kultuuroordrag en nie die opwek van die ware geloof deur die roepstem tot bekering nie, dan kan geloofsgemeenskap nie anders as om uit iets sigbaars te bestaan nie. Die eenheid van die kerk kan hier ook nie meer as 'n geloofseenheid gesien word nie, maar as 'n fisiessigbare werklikheid. Mens wil alleen glo en waardeer wat mens sien. As die prediking moet meehelp om die Koninkryk van Christus uit te brei, moet dit 'n koninkryk van hierdie wêreld wees, dus sigbaar in sy eenheid. Die koninkryk word hier inderdaad deur mensehande gebou en al wat menslik is, is sigbaar.

Artikel III gaan uit van die grondvooronderstelling dat Christus self vir Hom 'n gemeente bou en dat die gelowiges vir hierdie Gods-werk die Woord van God, die Evangelie, moet verkondig. Die Ryk van Christus is inderdaad nie 'n ryk van hierdie wêreld nie. En die eenheid van hierdie Ryk wat in die geloof aanvaar en bely word is ook nie 'n menslike ideaal nie, nie iets wat in die toekoms lê nie en nog deur die menslike aksie tot stand gebring moet word, maar dis werklikheid, dis geloofswerklikheid. Dit is 'n eenheid wat deur Christus self daar gestel is en deur Hom instand gehou word. Dit is dus 'n eenheid wat is en reeds bestaan en sy bestaan as geloofswerklikheid word elke dag opnuut bely deur die dankbare gelowige. Die opvatting dat die eenheid van die kerk 'n sigbare eenheid is wat nog bewerkstellig moet word deur die ywer van mense, is daarom nie uit die geloof gebore nie maar uit die ongeloof.

Die kerk mag God dank vir die pragtige formulering van hierdie geloofstellings in Artikel III; dank vir geestelike visie en leiding van die formuleerders daarvan. Mag die Nederduitsch Hervormde Kerk dit as ' $n$ kosbare kleinood bewaar vir en oordra aan die geslagte van gelowiges wat kom.

H. P. Wolmarans. 